\title{
花田卓也 学位論文審査要旨
}

$\begin{array}{ccccc}\text { 主査 } & \text { 佐 } & \text { 藤 } & \text { 慶 } & \text { 祐 } \\ \text { 副主査 } & \text { 重 } & \text { 政 } & \text { 千 } & \text { 秋 } \\ \text { 同 } & \text { 神 } & \text { 崎 } & & \text { 晋 }\end{array}$

\section{主論文}

Treatment with cyclohexenonic long-chain fatty alcohol reverses diabetes-induced tracheal dysfunction in the rat

（シクロヘキサノン長鎖アルコール治療はラットの糖尿病性気管障害を改善する）

（著者：花田卓也、齊藤源顕、神崎晋）

平成18年8月 Pharmacology 第78巻 51頁～60頁

\section{参考論文}

1.ゾニサミド投与中に腎尿路結石をきたした3例

(著者 : 林篤、花田卓也、神田貴行、神崎晋、笠置綱清、難波由貴子、岡明、宇都宮靖) 平成17年4月日本小児腎臓病学会雑誌 第18巻 27頁～31頁

2. B型肝炎ウイルス (HBV) genotype Aによる水平感染後に発症したHBV関連腎症の1男児例 (著者 : 林篤、花田卓也、神田貴行、村上潤、岡本学、飯塚俊之、長田郁夫、神崎晋、笠 置綱清、岡田隆好、宇都宮靖)

平成17年11月 日本小児腎臓病学会雑誌＼cjkstart第18巻 117 頁～121頁

3. 脳梗塞を発症し左片麻痺をきたした溶血性尿毒症症候群の1例

(著者: 岡田晋一、花田卓也、林篤、神田貴行、杉浦千登勢、前垣義弘、坂本誠、林原博、 神崎晋)

平成18年4月日本小児腎臓病学会雑誌 第19巻 31頁～36頁 


\section{学 位 論 文 要 旨}

\section{Treatment with cyclohexenonic long-chain fatty alcohol reverses diabetes-induced tracheal dysfunction in the rat}

\section{（シクロヘキサノン長鎖アルコール治療はラットの糖尿病性気管障害を改善する）}

糖尿病の合併症としての神経障害は二次的に臓器不全を生じさせる。気管平滑筋は副交 感神経の末端から遊離されたアセチルコリンによって収縮する。本研究では実験的に糖 尿病誘導モデルラットを作成し、収縮に密接に関係するムスカリン受容体のアゴニスト、 カルバコールの気管に対する収縮作用、同時にムスカリン受容体の分布、発現を免疫組 織化学的、分子生物学的手法を用いて検討した。一方、糖尿病の合併症の予防、治療に 効果を示していると報告されているシクロヘキサン誘導体は中枢神経培養細胞で成長因 子作用が見出された、分子量364の物質で、糖尿病誘発ラットで遅延した坐骨神経の伝導 速度の回復や、糖尿病性神経障害による大動脈、膀胱、小腸の過収縮を改善することが 認められている。本研究でも糖尿病誘発ラット気管の収縮性に対する効果およびムスカ リン受容体の分布、発現に対する効果を併せて検討した。

\section{方 法}

8週齢Sprague-Dawleyラットにストレプトゾトシン $50 \mathrm{mg} / \mathrm{kg}$ を腹腔内に単回注射し糖尿病 誘導モデルラットを作成した。なお、非糖尿病群には溶解液のみを注射した。糖尿病導入 後4週間で、(A) 非糖尿病コントロール群、(B) 糖尿病導入後4週間飼育群、(C) 糖尿病導入後 偽薬連日腹腔内投与群、（D）糖尿病シクロヘキサノン誘導体（2 mg/ $\mathrm{kg} / \mathrm{day})$ 連日腹腔内投 与群、（E）糖尿病シクロヘキサノン誘導体 $(8 \mathrm{mg} / \mathrm{kg} / \mathrm{day})$ 連日腹腔内投与群の5群に分け、 $\mathrm{B}$ 群は糖尿病導入後 4 週間、B群以外の 4 群は糖尿病導入後 8 週間飼育した。その後、ペントバ ルビタール腹腔内注射で麻酔後、下大静脈から採血し失血死させた。血液生化学検査では、 血糖值、血清インスリン值を測定した。また、気管組織を摘出し、3〜4個の気管軟骨ごと に輪状に切り、その輪状標本を使用してカルバコールに対する収縮機能実験を行った。ま た気管組織の厚さを測定した。Hematoxylin and eosin染色、ムスカリン受容体 $\mathrm{M}_{2}$ と $\mathrm{M}_{3}$ 抗体 での免疫組織染色で組織学的検討を行った。ムスカリン受容体 $\mathrm{M}_{2}$ ならびに $\mathrm{M}_{3}$ の抗体はAcris Antibodies GmbHから市販されているものを使用した。また、気管組織をホモジナイズし、 mRNAレベルでのムスカリン受容体 $\mathrm{M}_{2}$ と $\mathrm{M}_{3}$ の発現をリアルタイムPCR法で解析し評価した。統 
計学的処理にはFisher’s multiple comparison testを使用し、pく0.05を有意差ありとした。

\section{結 果}

糖尿病群では、糖尿病導入後4週間、8週間でいずれも非糖尿病コントロール群と比較し て体重が減少した。シクロヘキサン誘導体は体重変化に影響を与えなかった。血液生化学 検査上では、糖尿病導入群では非糖尿病コントロール群より有意に高血糖、低インスリン 血症を示した。シクロヘキサノン誘導体は高血糖、低インスリン血症には影響を与えなか った。気管壁の厚さの検討では、糖尿病の導入によって気管壁は菲薄化した。高用量（8 $\mathrm{mg} / \mathrm{kg} / \mathrm{day})$ だけではなく低用量（2 mg/ kg/day）のシクロヘキサノン誘導体投与でも気管 壁の菲薄化は有意に改善した。カルバコールに対する収縮機能実験での評価では、糖尿病 導入によって収縮反応の過敏性が増強したが、高用量だけではなく低用量でもシクロへキ サノン誘導体投与によって収縮反応の過敏性は改善した。Hematoxylin and eosin染色によ る組織学的検討では、非糖尿病コントロール群、糖尿病導入後偽薬連日腹腔内投与群、シ クロヘキサノン誘導体投与群のそれぞれの比較で、組織学的変化は確認できなかった。ム スカリン受容体 $M_{2}$ と $M_{3}$ 抗体を使用した免疫組織染色での組織学的検討では、 $M_{2}$ と $M_{3}$ ともに気 管平滑筋、膠原線維、線維芽細胞、粘膜上皮での染色が確認されたが、軟骨細胞、腺細胞 では染色されなかった。 $\mathrm{M}_{2}$ と $\mathrm{M}_{3}$ の分布部位はほぼ一致していた。気管組織のmRNAレベルで のムスカリン受容体 $\mathrm{M}_{2}$ と $\mathrm{M}_{3}$ の発現についてリアルタイムPCR法を用いて解析を行ったが、ム スカリン受容体 $M_{3}$ は糖尿病導入で過剩発現し、シクロヘキサノン誘導体投与で改善する傾 向にあった。ムスカリン受容体 $M_{2}$ は検出感度以下であった。

\section{考 察}

糖尿病誘導モデルラットの気管に対するシクロヘキサノン誘導体の効果を検討した。糖 尿病導入によって菲薄化した気管壁の厚さと増強した収縮反応の過敏性はシクロヘキサノ ン誘導体投与で有意に改善した。シクロヘキサノン誘導体は糖尿病での高血糖、低インス リン血症には影響を与えなかった。シクロヘキサノン誘導体は高血糖、低インスリン血症 を改善するのとは別の機序で神経障害を改善するものと考えられた。免疫組織染色での組 織学的検討では、気管での $\mathrm{M}_{2}$ と $\mathrm{M}_{3}$ の分布部位がほぼ一致していることが確認された。気管 組織のmRNAレベルでのムスカリン受容体 $\mathrm{M}_{2}$ と $\mathrm{M}_{3}$ の発現については組織量が非常に少なく、 $\mathrm{M}_{2}$ は検出感度以下であった。 $\mathrm{M}_{3}$ は糖尿病導入で過剩発現し、シクロヘキサノン誘導体投与 で改善する傾向にあった。これは糖尿病導入による神経障害のため、気管でのムスカリン 受容体 $\mathrm{M}_{3}$ のup-regulationがおこり、それをシクロヘキサノン誘導体が改善することを示唆 
している。

結 論

シクロヘキサノン誘導体は糖尿病導入によって誘導された気管の変化を可逆的に改善す る可能性がある。 